\title{
The Development, Transformation, and Use of The Children's Language
}

\section{Henny Dewi Koeswanti ${ }^{*}$}

${ }^{1}$ Pendidikan Guru Sekolah Dasar, Universitas Kristen Satya Wacana, Salatiga, Indonesia

\section{ART I CLE INFO}

Article history:

Received June 08, 2021

Revised June 11, 2021

Accepted August 03, 2021

Available online August 25, 2021

Kata Kunci:

Tranformasi Bahasa, Anak TK

Keywords:

language transformation;

kindergarten children

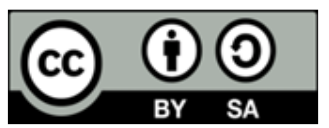

This is an open access article under the CC BY-SA license.

Copyright (ㅇ) 2021 by Author. Published by Universitas Pendidikan Ganesha.

\begin{abstract}
A B S T R A K
Masih banyak anak yang kesulitan dalam belajar bahasa asing. Selain itu, anak juga kesulitan dalam menghafal kosa kata bahasa asing. Perkembangan bahasa bagi anak-anak memiliki sifat yang dinamis karena ada banyak faktor yang dapat memengaruhinya. Tujuan penelitian ini yakni untuk mengidentifikasi berbagai macam bentuk perkembagan dan tansformasi bahasa yang dialami oleh santriwan dan santriwati TPA. Jenis penelitian ini yaitu penelitian kualitatif. Metode penelitian yang digunakan dalam penelitian ini yakni studi kasus tentang perkembangan, transformasi, dan penggunaan bahasa oleh anak-anak yang tergabung sebagai siswa TPA. Studi kasus ini dilakukan sebagai upaya untuk mengidentifikasi fenomenologi penggunaan dan perkembangan bahasa anak-anak yang dinamis melalui program TPA. Data dikumpulkan melalui cara observasi, dan wawancara. Teknik analisis data yaitu analisis deskriptif kualitatif. Hasil penelitian menunjukkan bahwa terdapat pengembangan, transformasi, dan penggunaan bahasa yang unik dan menarik yang dipengaruhi oleh konteks TPA sebagai ranah pendidikan informal berbasis pendidikan Islam. Hal tersebut terbukti dari berbagai macam bentuk bahasa yang digunkan oleh anak-anak yang mengalami perkembangan kosa kata hingga mengalami transformasi menjadi alih kode dan campur kode bahasa Arab. Penggunaan bahasa Arab dapat dipandang sebagai peluang karena mampu menambah pengetahuan dan kosa kata anakanak, namun sekaligus bisa juga dipandang sebagai ancaman terhadap kelangsungan bahasa lbu dan bahasa nasional bagi anak-anak.
\end{abstract}

\section{A B S T R A C T}

There are still many children who have difficulty learning foreign languages. In addition, children also have difficulty in memorizing foreign language vocabulary. Language development for children has a dynamic nature because many factors can influence it. This study aims to identify various forms of language development and transformation experienced by students and students of TPA. This type of research is qualitative research. The research method used in this study is a case study on the development, transformation, and use of language by children who are members of TPA students. This case study was conducted to identify the phenomenology of dynamic use and development of children's language through the TPA program. Data were collected through observation and interviews. The data analysis technique is descriptive qualitative analysis. The study results indicate that there is a development, transformation, and use of a unique and exciting language that is influenced by the context of TPA as the realm of informal education based on Islamic education. This is evident from the various forms of language used by children who experience vocabulary development until they are transformed into code-switching and Arabic code-mixing. The use of Arabic can be seen as an opportunity because it can increase children's knowledge and vocabulary, but at the same time, it can also be seen as a threat to the survival of the mother tongue and national language for children.

\section{INTRODUCTION}

Children are a group of individuals with a high level of sensitivity to language stimuli in the surrounding environment (Mulyaningtyas, 2019; Trisnanti et al., 2018). Children will readily accept new vocabulary and forms of language when they have socialized and interacted with their peers 
(Parvareshbar \& Ghoorchaei, 2016; Rahmat \& Akbar, 2019). This is natural because these individuals have a repertoire of language brought from the family environment, which is then transmitted and conveyed to their peers when communicating with each other. This is the beginning of children acquiring a second language after the mother tongue is used in the family environment (Guo \& Zhao, 2002; Paul \& Singh, 2020). This phenomenon is also in line with the dynamic nature of language. It develops according to the development of technology and the times and depends on the society of its users.

Language learning is also obtained when children enter kindergarten. When children go to school, children will be taught Indonesian and foreign languages. However, the current problem is that many children have difficulty learning foreign languages (Alam \& Lestari, 2020; Trisnanti et al., 2018). Many children have difficulty memorizing foreign language vocabulary (Liyana \& Kurniawan, 2019; Wijayanti, 2019). Whereas learning a foreign language will also train early childhood communication. This foreign language learning is also applied by one of the kindergartens. One of them is Taman Pendidikan Alquran (TPA). Taman Pendidikan Alquran (TPA) is a non-formal education that children often follow. The implementation of education through the TPA is carried out in mosques during the community. Children take part in the TPA education program to learn to read and write the letters of the Koran. In addition, they also get various kinds of learning things related to the religion of Islam. TPA also provides services and creates academic situations with Islamic religious nuances and adopts several things related to Arabic culture, one of which is basic Arabic in everyday life.

The use of Arabic instilled in children from an early age turns out to have negative and positive effects (Hasan \& Baroroh, 2019; Muhonen et al., 2020). The positive impact is that they can use Arabic as a polite and Islamic behavior (Fauzi et al., 2019; Ninoersy \& Akmal, 2020). The most obvious example is saying greetings 'assalamualaikum' every time children enter and leave the house and start activities by reading 'Bismillah.' On the other hand, there is an unfavorable impact on children's language development. This is evident from several examples of words that seem to be done in everyday life, while the interlocutor does not necessarily accept and feel comfortable with the Arabic language. For example, 'ana' means 'I' and 'antum,' which means you. Although it is a simple diction, it is a representation of the transformation and development of children's language in the field. This phenomenology deserves to be studied and identified correctly, considering that children must also be dominant in mastering their mother tongue and national language (Almaiah et al., 2020; Putri, 2017).

Language development is one of the indicators of a child's cognitive development. This is related to his successor's delay in thinking and communicating in his environment (Sokolova et al., 2018; Sun et al., 2021). A child who is slow in language can affect his daily communication skills personally or in his social environment (Paul \& Singh, 2020; Sokolova et al., 2018). The underlying conceptual model also influences second language acquisition experienced by children. The conceptual model has four main components consisting of sociocultural, linguistic, academic, and cognitive. The sociocultural aspect refers to the social conditions that underlie children interacting and asking questions about their culture (Alghazo et al., 2021; Sharif Matthews \& López, 2019).

The linguistic aspect refers to the language used by a child when communicating using words and sentences to the level of language variation, code-mixing, and code-switching (Andrade et al., 2014; Su et al., 2021). The academic aspect refers to formal and informal educational activities and their accompanying educational components. Finally, the cognitive aspect refers to the insight and knowledge possessed by each individual in the interaction process. These four things are mutually sustainable to form a conceptual model of language acquisition for children (Khong et al., 2017; Ratajczak, 2018). The linguistic component has an essential role in shaping the transformation and acquisition of language for children. The linguistic component consists of aspects of subconscious language development (the innate ability all humans have to acquire spoken language) and metalinguistics, which questions individual awareness of language learning. Mastery of the spoken and written language system experienced by children is experienced gradually starting from the acquisition of knowledge of phonology (pronunciation system), vocabulary, morphology, syntax (grammar system), semantics (meaning), pragmatics (context of language use), paralinguistics (nonverbal and other extralinguistic), and discourse (formal thought patterns) (Fauzi et al., 2019; Hariati, 2020). This depends on the ability of children to process information in their minds to respond to aspects of the language they receive (Khotimah et al., 2019; Zarei \& Afshar, 2014). Thus, language acquisition for children occurs gradually and is influenced by many factors, both linguistic and socio-cultural aspects, that overshadow children's interactions.

Other research findings also state that foreign language learning is very much needed by students (Fuad \& Helminsyah, 2018; Mauliate et al., 2019; Sokolova et al., 2018). The findings of previous studies stated that children who learn foreign languages would improve their communication skills berkomunikasi (Fuad \& Helminsyah, 2018; Lai \& Tai, 2021; Sokolova et al., 2018). So that foreign language learning is needed by early childhood. This study aims to identify various forms of language development 
and transformation experienced by students and students of TPA. It is hoped that teaching foreign languages to children will improve communication skills.

\section{METHOD}

This research on the development and transformation of children's language is a case study research based on phenomena during people's lives. Data were collected through observation and interviews with several sources relevant to this research. The data that has been observed is then identified comprehensively in order to conduct an analysis that is by the research needs, so that accurate results are obtained for this study. Furthermore, the data is analyzed continuously until the data is saturated. The data analysis uses Miles and Huberman model analysis, namely from data collection, data reduction, data display, and verification (Miles \& Huberman, 2007). As for data validation in this study using source triangulation techniques, where the same or similar data will be extracted from several students. The objects of this research are children who are TPA students at a mosque in the Sukoharjo area, Central Java, who use several languages in their social interactions, namely their mother tongue and Javanese, the national language, namely Indonesian, and another language, namely Arabic, which is the impact of socio-cultural aspects. And linguistics in their landfill environment. This research focuses on the development of mastery of Arabic vocabulary by children, which is then used and implemented in the family and community environment.

\section{RESULT AND DISCUSSION}

\section{Result}

Children's language skills can be seen and assessed directly from their speaking ability when communicating with others. These language skills are also in line with children's language development in various social situations. Children are allowed to explore different ways and styles of speaking for different situations and interlocutors. In a communication situation between children, speaking and listening skills are essential points in language development. The things that the children hear are usually put into practice immediately, and if there are new words, they will also be used to balance the style and way their friends speak. Many things are related to language development in children, especially about language development in TPA students, including the nature of language development, children's language development, development of oral communication; development of written communication; and development of reading and writing. The age of elementary school children, namely TPA students, is the best time to form language characters in children from middle school age or adolescence. It must also be realized by teachers and parents to have new references that are more accurate in shaping the character of children's language skills by applying various learning theories and continuing to develop. In this case, children's language development is closely related to several aspects of children's physical and motoric characters, perception development, language development characters, development of independence, and career development (Kurnia et al., 2015; Triutami et al., 2014).The existence of TPA as a place for children to carry out education, interaction, and career development for children provides a wide gap to influence children's language development, one of which is manifested in new vocabulary in the form of Arabic, which is used in their interactions in the TPA, family, school environment. To the community. This phenomenon is undoubtedly a sieve to be studied and researched comprehensively.

The use of Arabic, which children in daily life do, is their right and cannot be prohibited. Besides that, it is also a natural thing in communicating. It is a form of self-expression and existence and pride to show others that they can apply the habits of TPA in their lives. Psychologically, children also feel more confident because the indicators in the TPA learning program can be met by direct practice in the field. In addition, they interact and communicate by mixing the Arabic code as a direct learning step and practicing their knowledge. Here are some examples of conversations that children have in their environment.

Quote 1

(1) A : "Assalamualaikum, Ma! The landfill is complete."

(2) B : "Yes, Nduk, Waalaikumsalam. Please immediately change and remove the hijab!

(3) A : "Yes, Ma'am. Oh yes, my pond was borrowed by Anggun to write."

(4) B : "What is the pool? I don't know that!"

(5) A : "The pool is a pen, it's Arabic, I don't know, Mak."

(6) B "As far as I know, a pen is not a pool, a pen is clear."

(7) A: "I was told to learn and practice Arabic by my teacher" 
The excerpt of the speech event above occurred between a girl who had just returned from the TPA and her mother, who was at home. In this communication, children use code-mixing with Arabic. The mother who received the Arabic vocabulary felt uncomfortable because she did not know and was unfamiliar with the Arabic diction 'kolamun,' which means 'bullpen in Indonesian. According to the child's version, this is a natural thing and should be accepted by everyone because he thinks what he is doing is a direct practice of what he has learned. On the other hand, the child's mother feels strange and uncomfortable with the new diction because it is not commonly used and thinks that it is only a knowledge of Arabic dictions and does not have to be used in the family or community environment.

Quote 2

(1) C : "Heeiii....., ahlan wa syahlan, where are you going Keisya?"

(2) D : "Alhamdulillah, ahlan bika. Anu Nggun, do you want to buy white milk or not?

(3) C : "I don't want to go with you."

The conversation in quote two above occurs between a child and a child who asks the intentions and goals of his friend who wants to go somewhere. Then, the answer from the child was to explain that he wanted to go to a grocery shop to buy sweetened condensed milk. In the conversation, there were mixed codes of Arabic use in the form of diction Ahlan wa siphon, which means "how are you?', 'Ahlan bika' which means 'all right,' 'ana' which means 'I', and 'antum' which means 'you.' This is an example of the use of Arabic by two children which is a direct practical step by TPA students. The use of Arabic diction in ana, antum, pondun, ahlan wa syahlan, and ahlan bika above personally and seen on the surface is a normal and natural phenomenon by TPA students. However, if viewed from the development and transformation of children's language, this must get special attention because it will impact children in the future. The thinking of the children who are still limited and think practically makes them use the Arabic language based on the teacher's advice. However, what should be considered is if the use of the Arabic code becomes an obligation and necessity in everyday life. This will interfere with children's language development because children who study and practice their mother tongue and national language correctly and adequately are tucked away with new Arabic vocabulary, which is considered more Islamic and 'cool' in the eyes of others who do not know its meaning.

3 quote

(1) C : "Najwa, you bought a new bag, right? Barakallahu fikum yes!"

(2) D : "Thank God, I did buy Om Agus a new bag at the Tawangsari Gift Palace."

(3) C: Wow, I'm really happy, Najwa, the bag is new, masyAllah."

(4) D : "Yes, please, Syukron, Nguun..."

The use of Arabic Barakallahu fikum means May Allah give you blessings. The purpose of the utterance is the prayer that Child $C$ conveyed to $\mathrm{D}$ that he intended to convey respect and happiness for his friend who bought him a new bag. Child $\mathrm{C}$ also prays that what has been obtained and owned by child $\mathrm{D}$ will be a blessing and valuable. Then, he also equated thank you with the choice of syukron diction, which means I am grateful. The use of the diction alhamdulillah and masyaAllah above is also a form of gratitude and admiration for God's grace related to the speech event conveyed by the child expressively.

\section{Discussion}

Language skills are direct communication access in various environmental communities that allow the emergence of a complex and sustainable social atmosphere (Ang et al., 2017; Cekaite, 2017). Communication skills are constantly changing and relatively developing, adapting to the context and development of the conversation. Language skills always give and are influenced by several factors, namely external and internal factors in the psychology of children's thinking (House et al., 2021; Iannuccilli et al., 2021; Suardi et al., 2019). Children's language skills and development are also basic when interacting and communicating. The problems of language development and transformation experienced by children need to be considered by teachers and parents. Teachers and parents must realize that the child's brain is very receptive to stimuli and accepts all forms of information (Djou \& Ntelu, 2021; Triutami et al., 2014). Therefore, when interacting in the community, children's language must also be considered and given special filters so that they are not trapped in the transformation of lousy language use (Akbar, 2015; Alam \& Lestari, 2020). Children should be given the best possible explanation that they must distinguish language that should be used daily from language only used as a provider of knowledge (Hulukati et al., 2017; Suardi et al., 2019). Thus, they will be wiser and orderly in using everyday language. 
The environment is one of the factors that has a considerable influence on children's language development because with the environment, and children can live their daily lives well without any difficulties in interacting (Nuraeni et al., 2019; Rosalina, 2011). The stimulus that the child gets from the environment will affect the child's language development. Stimuli that are received will slowly affect children's language development (Kurniawati, 2019; Liyana \& Kurniawan, 2019). Stimulus from the closest people, namely parents, will be processed by the child to mature in thought patterns, action patterns, and speech patterns (Liyana \& Kurniawan, 2019). This must be a particular concern and consequently by parents and teachers to guide the development of children wisely. In addition, the cultivation of the mother tongue and national language must be prioritized over the cultivation of a second language such as Arabic.

The socio-cultural aspect is also very influential on the further development of children in terms of mastery and use of language (Sokolova et al., 2018; Sun et al., 2021). Teachers and parents must synergize well to shape children's character in communicating well through the development and use of everyday language (Khong et al., 2017; Ratajczak, 2018). Children must be given the best understanding and knowledge that in learning Arabic, they do not have to force themselves to cultivate Arabic and even apply Arabic culture. Education about language, culture, and national identity must be applied to children early (Mulyaningtyas, 2019; Suardi et al., 2019). This is done as an effort to keep children from being easily influenced by outside cultures. The provision of knowledge about the use and mastery of the mother tongue and national language above other languages also needs to be instilled in children to understand the conception and corridors of language use comprehensively. It also refers to the principle that prevention is better than cure. In the context of the use, transformation, and development of children's language, teachers and parents should maintain and provide the best possible education to develop according to their age and understand the whole concept of culture and nationalism.

\section{CONCLUSION}

The development and transformation of children's language are influenced by sociocultural, social environment, cognitive, and linguistic development. This is reflected in the use, development, and transformation of the language of TPA students who use Indonesian (national language), Javanese (mother tongue), and Arabic (second language development). What also needs to be considered is that children who have limited thinking must be given language knowledge and cultural education from an early age to create conditions for individuals who are ready from an early age.

\section{REFERENCES}

Akbar, A. (2015). Pemerolehan Morfem Afiks Bahasa Indonesia Anak Usia 2-6 Tahun Di Paud Buana Desa Banyu Urip Kabupaten Lombok Tengah. RETORIKA: Jurnal Bahasa, Sastra, Dan Pengajarannya, 1(2). https://doi.org/10.22225/jr.1.2.32.250-257.

Alam, S. K., \& Lestari, R. H. (2020). Pengembangan Kemampuan Bahasa Reseptif Anak Usia Dini dalam Memperkenalkan Bahasa Inggris melalui Flash Card. Jurnal Obsesi : Jurnal Pendidikan Anak Usia Dini, 4(1), 284. https://doi.org/10.31004/obsesi.v4i1.301.

Alghazo, S., Zemmour, S., Salem, M. N. Al, \& Alrashdan, I. (2021). A cross-cultural analysis of the speech act of congratulating in Kabyle and Jordanian Arabic. Ampersand, 8. https://doi.org/10.1016/j.amper.2021.100075.

Almaiah, M. A., Al-Khasawneh, A., \& Althunibat, A. (2020). Exploring the critical challenges and factors influencing the E-learning system usage during COVID-19 pandemic. Education and Information Technologies, 25(6), 5261-5280. https://doi.org/10.1007/s10639-020-10219-y.

Andrade, M. S., Evans, N. W., \& Hartshorn, K. J. (2014). Linguistic support for non-native English speakers: Higher education practices in the United States. Journal of Student Affairs Research and Practice, 51(2). https://doi.org/10.1515/jsarp-2014-0020.

Ang, S., Embi, M. A., \& Yunus, M. M. (2017). Strategies of Successful English Language Learners among Private School Students. Jurnal Pendidikan Humaniora, 5(2), 47-57. https: //doi.org/10.17977/um030v5i22017p047.

Cekaite, A. (2017). What Makes a Child a Good Language Learner? Interactional Competence, Identity, and Immersion in a Swedish Classroom. Annual Review of Applied Linguistics, 37, 45-61. https: //doi.org/10.1017/S0267190517000046.

Djou, D. N., \& Ntelu, A. (2021). Bahasa Gorontalo dan Bahasa Suwawa pada Anak Usia Dini. Jurnal Obsesi, 5(2). https://doi.org/10.31004/obsesi.v5i2.895.

Fauzi, M. F., Buhun, M. F., \& Purwadi, A. (2019). The Influence of Teams Games Tournament (TGT) toward 
Students' Interest in Arabic Language Learning. Journal Of Arabic Languange Teaching, Linguistic and Literate, 2(2). https://doi.org/10.22219/jiz.v2i2.9986.

Fuad, Z. Al, \& Helminsyah. (2018). Language Experience Approach Sebuah Pendekatan Dalam Meningkatkan Keterampilan Menulis Siswa Sekolah Dasar. Jurnal Tunas Bangsa, 5(2), 164-174. https://doi.org/10.46244/tunasbangsa.v8i1.

Guo, L., \& Zhao, Z. (2002). Children, gender, and language teaching materials. Chinese Education and Society, 35(5), 34-52. https://doi.org/10.2753/ced1061-1932350534.

Hariati, P. H. (2020). Illocutionary Acts in Jack Ma's Inspiring Speech in His Graduation at The University of Hongkong. Britain International of Linguistics, Arts and Education, 2. https://doi.org/10.33258/biolae.v2i1.209.

Hasan, A. A., \& Baroroh, U. (2019). Pengembangan Media Pembelajaran Bahasa Arab Melalui Aplikasi Videoscribe Dalam Meningkatkan Motivasi Belajar Siswa. Lisanuna: Jurnal Ilmu Bahasa Arab Dan Pembelajarannya, 9(2). https://doi.org/10.22373/ls.v9i2.6738.

House, J., Kádár, D. Z., Liu, F., \& Bi, Z. (2021). Altered speech act indication: A problem for foreign language learners? System, 101. https://doi.org/10.1016/j.system.2021.102554.

Hulukati, W., Rahim, M., \& Djafar, Y. (2017). Pembelajaran Bahasa Daerah Gorontalo Pada Anak Usia Dini. VISI: Jurnal Ilmiah Pendidik Dan Tenaga Kependidikan Pendidikan Non Formal, 12(1). https: //doi.org/10.21009/JIV.1201.8.

Iannuccilli, M., Dunfield, K. A., \& Byers-Heinlein, K. (2021). Bilingual children judge moral, social, and language violations as less transgressive than monolingual children. Journal of Experimental Child Psychology, 208. https://doi.org/10.1016/j.jecp.2021.105130.

Khong, H. K., Hassan, N. H., \& Ramli, N. (2017). Motivation and gender differences in learning Spanish as a foreign language in a Malaysian Technical University. Malaysian Journal of Learning and Instruction. https://doi.org/10.32890/mjli2017.14.2.3.

Khotimah, K., Widiati, U., Mustofa, M., \& Faruq Ubaidillah, M. (2019). Autonomous English learning: Teachers' and students' perceptions. Indonesian Journal of Applied Linguistics, 9(2), 371-381. https://doi.org/10.17509/ijal.v9i2.20234.

Kurnia, D., Taufiq, M., \& Silawati, E. (2015). Analisis Capaian Perkembangan Bahasa Anak Usia Dini Dalam Kegiatan Pembelajaran Dengan Metode Learning Based Resources. Cakrawala Dini: Jurnal Pendidikan Anak Usia Dini, 6(2). https://doi.org/10.17509/cd.v6i2.10520.

Kurniawati, D. (2019). Keefektifan Pengajaran Kosakata Bahasa Inggris Pada Anak Sekolah Dasar Dengan Menggunakan Flash Card. Jurnal Pendidikan Dan Pembelajaran Dasar, 2(2), 59. https://doi.org/10.37484/manajemen_pelayanan_hotel.v2i2.40.

Lai, C., \& Tai, C.-P. (2021). Types of social media activities and Hong Kong South and Southeast Asians Youth's Chinese language learning motivation. System, 97. https://doi.org/10.1016/j.system.2020.102432.

Liyana, A., \& Kurniawan, M. (2019). Speaking Pyramid sebagai Media Pembelajaran Kosa Kata Bahasa Inggris Anak Usia 5-6 Tahun. Jurnal Obsesi: Journal of Early Childhood Education, 3(1). https://doi.org/10.31004/obsesi.v3i1.178.

Mauliate, H. D., Rahmat, A., \& Wachidah, S. (2019). Evaluation the Lesson Plan of English Language Learning in Junior High School, Seraphine Bakti Utama West Jakarta. International Journal of Scientific Research and Management, 7(07), 1078-1086. https://doi.org/10.18535/ijsrm/v7i7.el02.

Miles, \& Huberman. (2007). Analisis Data Kualitatif. Universitas Inggris.

Muhonen, H., Pakarinen, E., Lerkkanen, M.-K., Barza, L., \& Suchodoletz, A. von. (2020). Patterns of dialogic teaching in kindergarten classrooms of Finland and the United Arab Emirates. Learning, Culture and Social Interaction, 25. https://doi.org/10.1016/j.lcsi.2018.11.011.

Mulyaningtyas, R. (2019). Stimulasi Dalam Memaksimalkan Kemampuan Berbahasa Anak Usia Dini. Martabat: Jurnal Perempuan Dan Anak, 3(1). https://doi.org/10.21274/martabat.2019.3.1.121140.

Ninoersy, \& Akmal. (2020). Penerapan Pola Perkuliahan Muhadatsah Melalui Metode Debat Aktif Pada Prodi Pendidikan Bahasa Arab Fakultas Tarbiyah Dan Keguruan Uin Ar-Raniry Banda Aceh. Jurnal Ilmiah Didaktika: Media Ilmiah Pendidikan Dan Pengajaran, 20(2), 165 - 188. https: //doi.org/10.22373/jid.v20i2.5478.

Nuraeni, S., Maesaroh, A., \& Sumitra, A. (2019). Optimalisasi Keterampilan Berbicara Untuk Meningkatkan Keyakinan Diri Anak Usia Dini Di Tk Baiturrahman Kabupaten Bandung. CERIA (Cerdas Energik Responsif Inovatif Adaptif), 2(4). https://doi.org/10.22460/ceria.v2i4.p166-172.

Parvareshbar, F., \& Ghoorchaei, B. (2016). The Effect of Using Short Stories on Vocabulary Learning of Iranian EFL Learners. Theory and Practice in Language Studies, 6(7), 1476. 
https://doi.org/10.17507/tpls.0607.20.

Paul, R., \& Singh, A. (2020). Does early childhood adversities affect physical, cognitive and language development in indian children? Evidence from a panel study. SSM - Population Health, 12(August), 100693. https://doi.org/10.1016/j.ssmph.2020.100693.

Putri, W. N. (2017). Pengaruh Media Pembelajaran Terhadap Motivasi Belajar Bahasa Arab Siswa Madrasah Tsanawiyah. LISANIA: Journal of Arabic Education and Literature, 1(1), 1-16. https://doi.org/10.18326/lisania.v1i1.1160.

Rahmat, A., \& Akbar, M. (2019). A Comparative Analysis of English Learning Motivation between the Rural and Urban Students. Metathesis: Journal of English Language, Literature, and Teaching, 3(2), 158. https://doi.org/10.31002/metathesis.v3i2.1740.

Ratajczak, M. (2018). Language and value: the philosophy of language in the post-Operaist critique of contemporary capitalism. Language Sciences, 17. https://doi.org/10.1016/j.langsci.2018.08.004.

Rosalina, A. (2011). Peningkatan Kemampuan Bahasa Anak Usia Dini Melalui Kegiatan Bermain. Psycho Idea, 9(1), 19-35. https://doi.org/10.30595/psychoidea.v9i1.239.

Sharif Matthews, J., \& López, F. (2019). Speaking their language: The role of cultural content integration and heritage language for academic achievement among Latino children. Contemporary Educational Psychology, 57, 72-86. https://doi.org/10.1016/j.cedpsych.2018.01.005.

Sokolova, E. Y., Golovacheva, E. A., \& Chernaya, A. A. (2018). Professionally-Oriented Communicative Language Teaching Approach by the Design of a Computer Assisted ESP Course: Analysis of Results. Procedia - Social and Behavioral Sciences, 215. https://doi.org/10.1016/j.sbspro.2015.11.619.

Su, H., Zhang, Y., \& Lu, X. (2021). Applying local grammars to the diachronic investigation of discourse acts in academic writing: The case of exemplification in Linguistics research articles. English for Specific Purposes, 63. https://doi.org/10.1016/j.esp.2021.05.002.

Suardi, I. P., Ramadhan, S., \& Asri, Y. (2019). Pemerolehan Bahasa Pertama pada Anak Usia Dini. Jurnal Obsesi : Journal of Early Childhood Education, 3(1). https://doi.org/10.31004/obsesi.v3i1.160.

Sun, T., Wang, C., Lambert, R. G., \& Liu, L. (2021). Relationship between second language English writing self-efficacy and achievement: A meta-regression analysis. Journal of Second Language Writing, 53. https://doi.org/10.1016/j.jslw.2021.100817.

Trisnanti, I. A. N. L., Tirtayani, L. A., \& Putra, I. K. A. (2018). Pengaruh Media Flashcard Bilingual Terhadap Kemampuan Kosakata Bahasa Inggris Permulaan Anak Kelompok B TK Gugus Mawa. Journal Pendidikan Anak Usia Dini Undiksha, 6(3), 346. https://doi.org/10.23887/paud.v6i1.15200.

Triutami, I. G. A. A. D., Sudhita, I. W. R., \& Tegeh, I. M. (2014). Penerapan Metode Bercerita Berbantuan Media Boneka Tangan Untuk Meningkatkan Perkembangan Bahasa Pada Anak. Jurnal Pendidikan Anak Usia Dini, 2(1). https://doi.org/10.23887/paud.v2i1.3239.

Wijayanti, D. N. (2019). Effective learning of English through children's songs for madrasah ibtidaiyah (MI) students. Elementary, 4(1), 124-148. https://doi.org/10.21043/elementary.v4i1.1931.

Zarei, A. A., \& Afshar, N. S. (2014). Multiple Intelligences As Predictors Of Reading Comprehension And Vocabulary Knowledge. Indonesian Journal of Applied Linguistics, 4(1). https://doi.org/10.17509/ijal.v4i1.598. 